UDC: 001.8:005.334.658.15:657.635

JEL Classification: L 26

S. V. SELISHCHEV,

PhD (Economics),

Associate Professor of National Center for Accounting and Audit,

National Academy of Statistics, Accounting and Audit

\title{
Selected Issues of Using International Standards of Auditing When Assessing the Application of the Going Concern Basis by Management Personnel of a Company
}

The article deals with selected issues of the application of international standards of audit in domestic practice. The source of the main problem, which hinders the development of a unified methodological approach to the application of international standards, is determined, and proposals for its solution are provided. Particular attention is paid to the methodological recommendations for reflecting the requirements of international standards in the auditor's working papers.

The investment activity of foreign partners in Ukraine is conditional on the financial statement clarity for domestic business entities and their trust in them. While the former can achieved by the application of International Financial Reporting Standards, the latter is dependent on the application of International Standards of Auditing (ISA).

The purpose of the article is to develop a methodological approach to the application of ISA, based on clarification of their essence and nature.

The study of audit practice and opinions of users of audit reports shows that one of the key issues is compliance with the going concern basis of accounting by management personnel in preparing financial statements.

It can be concluded from the study that ISA do not conform to the definition of "standards", being more similar with some kind of "rules". It means that ISA constitute the rules for performing audit by focusing the auditor attention on a specific set of issues and objects. This approach allows for a certain extent of control over the completeness the audit process and for assuring selected aspects of quality.

Keywords: audit, International Standards of Auditing, the going concern basis of accounting, financial statement, working documents.

Introduction. International Standards of Auditing have been introduced in audit practice in Ukraine as national ones, in particular the standards adopted by the International Federation of Accountants and Auditors in 2005. This approach is fully justified because of the need to stimulate integration of the Ukrainian economy in the global financial and economic community, first and foremost by attracting more investment. The scopes of foreign partners' investment in Ukraine are conditional on how well the financial statements are understood and trusted by domestic business entities. While the former can be achieved by using International Standards of Financial Reporting, the latter is dependent on the International Standards of Auditing (ISA).

The analysis of current practices shows that the largest number of methodical problems is associated with the application of ISA, and they occur mostly due to misunderstanding of ISA nature and essence. Their solutions will lay the ground for elaborating the methodology for the application of ISA in the national practice of audit, which raises the importance of this study.

Review of studies and publications. Studies devoted to rethinking and adaptation of theoretical approaches highlighted in works of national and foreign researchers $[1-5 ; 7-10]$ to the methods and methodologies involved in the application of ISA in the domestic practice of audit are thematically relevant to this study.

The objective of this article is to develop a methodology for the application of ISA by specifying their essence and characteristics, in the context of the application of the going concern basis of accounting by company management personnel.

(C) S. V. Selishchev, 2018 
Results. The previous studies of audit practices and opinions of users of auditor reports show that a central issue is the observance of the going concern basis of accounting by management personnel in making up financial statements. First, "the going concern" is a central principle underlying most part of the financial reporting frameworks. Second, the question "Will a business entity continue and for what period?" is a main issue of concern for users of financial statements.

The responsibilities and actions involved in checking the correctness of assessment of the application of the going concern basis of accounting are regulated by ISA 570 "Going Concern".

ISA 570 establishes:

- the scopes of application;

- the going concern basis of accounting;

- the responsibility for the assessment of the business entity's ability to continue;

- the data of enforcement;

- the objectives;

- the procedures for risk assessment and relevant actions;

- the evaluation of the assessment performed by management personnel;

- the period after the assessment performed by management personnel;

- additional auditor procedures when events or conditions are identified;

- auditor's conclusions and reports;

- the use of the going concern basis of accounting;

- acceptable, but the significant uncertainty exists;

- the use of the going concern basis of accounting is inacceptable;

- the disinclination of management personnel to perform or extend the assessment;

- communicating the information to the persons assigned with supreme authorities;

- a considerable delay with approval of financial statements [6, p. 578].

The textual analysis of ISA 570 shows that no specific methodological recommendations are given. A review of interpretations of "standard" and "rule" is proposed below, to define the real purpose of ISA 570 in a correct manner.

"Standard" in a broader sense means a sample, a gauge or a model taken as original one, in order to compare other similar objects with them [11, p. 364].

"Rule" refers to the requirement to have certain conditions (norms of behavior) met by everybody engaged in an action (a play, orthography, a legal process, an organization or an institution), involving stimuli once it is met and penalties ones it fails to be met [11, c. 267].

It can, therefore, be seen that ISA 570 do not have features of "sample" for the process of auditing financial statements, i. e. they do not have a clear algorithm for actions with specifying the actions' meaning and the techniques for performing them; they rather have features of "rule", i. e. they contain a set of requirements for performing an action.

Below we are going to show selected requirements ISA 570 and their descriptions in working documents.

ISA 570 specifies the responsibility of an auditor that financial statements should be made by management personnel on the going concern basis of accounting. Because this provision of ISA 570 is informational, there is no reason to have it reflected in working documents.

While general purpose financial statements are made on the going concern basis of accounting, other statements do not necessary involve this basis as the central one. An auditor, therefore, needs to specify the reporting framework.

Assets and liabilities are recorded on the basis that the entity will be able to realize its assets and discharge its liabilities in the normal course of business. The way of recording assets and liabilities needs, therefore, to be specified and reflected in working documents.

The going concern basis of accounting can also be used in the public sector. A risk can occur when financial aid to a non-profit organization is reduced or abrogated, or when it is subject to privatization. When long-term financing or political decisions with impact on the entity's operation are lacking, the share of public capital in the equity of an entity needs to be either determined or indicated as non-existent.

Some of the conceptual frameworks for financial reporting, standards and regulations contain the requirement on performing obligatory assessment of the risk of termination of operation (for example, International Accounting Standards 1). It, therefore, needs to be 
determined if a conceptual framework for the audited statements contain the obligatory requirement on assessment of risk of termination of operations.

Some of the conceptual frameworks may not contain the requirement on performing obligatory assessment of the risk of termination of operations, but because the going concern basis of accounting is the fundamental one, assessment of the risk of termination of operations must be obligatory for everybody. It means that according to ISA 570 assessment of the risk of termination of operations needs to be performed all the time.

The judgment on the assessment of the risk of termination of operations is conditional on factors such as remoteness of an event in the future, size and complexity of a business entity, information support. An auditor is responsible for producing sufficient and relevant arguments regarding the acceptability of the management personnel's assessment of the risk of termination of operation, if even these requirements are not involved by the conceptual framework.

Absence of information about the existence of the risks of termination of operations in the auditor's report does not guarantee that these risks cannot occur.

The auditor's objective is to find evidence for the feasibility of use of the going concern basis of accounting, to determine the degree of uncertainty and show this information in the report.

An auditor must check if management personnel have performed assessment of continuity. If they have, an auditor need to consider whether events or conditions exist that may cast significant doubt on the entity's ability to continue as a going concern. If otherwise, an auditor must discuss the framework for using the going concern basis of accounting with management and specify the occurrence of factors that may affect it.

The fact of performing the continuity assessment, the identified facts that may cast doubt on the continuity, and the facts that may affect the framework for use of the going concern basis of accounting need to be reflected in the working documents.

The consequences of failure to repay debts in timely manner can be compensated by management plans for alternative ways of monetary incomes: disposal of assets, restructuring of debts or raising of additional capital, alternative buyers or suppliers. Therefore, the fact of the consequences of failure to repay debts in timely manner and the fact of the existence of sources for their compensation (without a detailed list) need to be reflected in the working document.

On the one hand, small enterprises can quickly react and utilize their opportunities, but, on the other hand, they do not have the reserves for continuing operation: banks may not want to lend them; they may lose the key supplier or buyer, or the key worker, or the license etc. Therefore, when auditing a small enterprise, the fact of existence or absence of reserves for the continuing operation needs to be determined.

During the entire period of audit, an auditor must be mindful of the evidences of discontinuity; if these evidences are identified after the continuity assessment has been performed he must revise the risk assessment once again. An auditor must regularly perform evaluation of the management personnel's assessment, because it is crucial to the assessment of the feasibility of the going concern basis of accounting.

If management personnel have not performed the continuity assessment, an auditor can be satisfied by his own assessment (but he is not responsible for correcting the situation in other cases). In other circumstances, the auditor's evaluation of the assessment performed by management personnel is based on the mechanism for evaluation of management plans. The fact of the continuity assessment by management personnel needs to be reflected in case of small enterprise.

As small enterprises depend on the financial capacity of their proprietors-directors, an auditor needs to have evidence of the proprietor-director's capacity for business financing, and to determine if the proprietor-director can really invest in the small enterprise.

Upon receiving the continuity assessment from management personnel, an auditor needs to make sure that it correlates with the assessment made by him. An auditor, therefore, should reflect the fact that the assessment performed by management personnel is similar with his own one.

An auditor must make a request to management personnel on whether or not they are aware of events or conditions occurring after the assessment, which may threaten to the 
entity's ability to continue as a going concern. Also, an auditor has the responsibility for performing the procedures for identification of such events or conditions for twelve months after the statement date.

Apart from requests to management personnel, an auditor is responsible for performing the procedures required for identification of the abovementioned events and conditions.

The fact of the auditor's request to management personnel needs to be reflected in the working documents.

When an auditor identifies events or conditions that may cast doubt on the continuity assessment, he must receive acceptable audit evidences of the assessment correctness, including extenuating circumstances. Presence or absence of events or conditions casting doubt on the continuity assessment performed by management personnel need to be reflected. On the basis of the evidence received, an auditor must find out what events or conditions may cast doubts on the entity's ability to continue as a going concern.

It needs to be signified in the working documents if the going concern basis of accounting is used adequately and if a significant uncertainty exists. It needs to be specified if the information drawing the user's attention to the fact of probable failure to continue is disclosed in a proper way. If the financial reporting discloses such information in a proper way, an auditor must express the non-modified judgment, with including it in the explanatory paragraph where the existence of a significant uncertainty and the reasons for its occurrence are highlighted.

An auditor can avoid expressing the judgment and supplementing the explanatory paragraph when large numbers of significant uncertainties are identified.

An auditor must indicate whether or not the information is disclosed in the financial statement in a proper manner and whether or not the fact of the existence of large numbers of distortions or reporting on an alternative basis exists.

The fact of engaging all the persons with supreme authorities in management activities, the fact of management personnel's delays with statements or assessment and their effects for risks of termination of operation should be reflected.

A sample of the working document is illustrated in Table.

Table

The working document of an auditor on the assessment of the risk of termination of company's operation, performed by management personnel (ISA 570)

\begin{tabular}{|r|l|c|c|}
\hline No & \multicolumn{1}{|c|}{ Action } & Yes & No \\
\hline 1. & The report is made under a common framework & & \\
\hline 2. & $\begin{array}{l}\text { Assets and liabilities are recorded on the basis that the entity will be able to } \\
\text { realize its assets and discharge its liabilities in the normal course of business. }\end{array}$ & & \\
\hline 3. & The existence of public capital in the equity. & & \\
\hline 4. & $\begin{array}{l}\text { The obligatory requirement on assessment of the risk of termination of } \\
\text { operation fixed in the conceptual framework. }\end{array}$ & \\
\hline
\end{tabular}

Source: developed by the author on the basis of ISA 570 "Continuity of Operation" [6, p. 578-605]

It can be seen that while some of ISA 570 provisions are merely informative, other contain instructions on what needs to be cared. But is should be noted that neither of ISA 570 provisions contains an algorithm of actions or a method on how "the requirements" of this standard should be met.

Conclusions. A theoretical and methodological framework for the application of ISA in audit practices does not really exist because of the absence of a single methodological approach. Due to this, ISA tend to be in a way neglected by practical auditors.

It can be concluded from the study that ISA do not conform to the definition of "standards", being more similar with some kind of "rules". It means that ISA constitute the rules for performing audit by focusing an auditor on a predefined set of issues and objects. This approach allows for a certain extent of control over the completeness of the audit process and for the assurance of selected quality components. 


\section{References}

1. Butynets F. F. (2001). Audyt i reviziya pidpriyemnitskoyi diyalnosti [Audit and revision of business operation]. Zhytomyr: PP "Ruta" [in Ukrainian].

2. Danilevskyi Yu. A., Shapiguzov S. M., Remizov N. A. \& Starovoitova E. V. (2000). Audit [Auditing]. Moscow: ID FBK-PRESS [in Russian].

3. Honcharuk Y. A. (2002). Audyt [Auditing]. Lviv: Svit [in Ukrainian].

4. Davidov G. M. (2004). Audyt [Auditing]. Kyiv: Liga [in Ukrainian].

5. International Accounting Standards and Financial Reporting Standards: [Electronic Resource] / Official Website of the Verkhovna Rada of Ukraine. URL: http://zakon3. rada.gov.ua/laws/show/929_010 [in Ukrainian].

6. Kulakovska L. P. \& Picha Ȳu. V. (2009). Orhanizatsiya i metodyka audytu [Organization and methods of auditing]. Kyiv: Karavela [in Ukrainian].

7. Petrik O. A. (2003). Audyt: metodolohiya ta orhanizatsiya [Auditing: methodology and organization]. Kyiv: KNEU [in Ukrainian].

8. Proskurina N. M. (2011). Protsedurne zabezpechennya audytu. Teoriya ta praktyka [Procedures of auditing: theory and practice]. Kyiv: DP "Inform.-analit. ahentstvo" [in Ukrainian].

9. Redko A. Yu. (2008). Audyt v Ukrayini. Morfolohiya: [Audit in Ukraine. Morphology]. Kyiv: DP "Inform.-analit. ahentstvo" [in Ukrainian].

10. Savchenko V. Ya. (2002). Audyt [Audit]. Kyiv: KNEU [in Ukrainian].

11. Dictionary of philosophical terms (2011). 2nd ed., ext. and corrected. Kemerovo [in Russian].

С. В. СЕЛІЩЕВ,

кандидат економічних наук,

доиент Національного центру обліку та аудиту, Національна академія статистики, обліку та аудиту,

\section{Окремі питання використання міжнародних стандартів аудиту при оцінці застосування принципу безперервності управлінським персоналом підприсмства}

В рамках дослідження питань використання міжнародних стандартів аудиту при оцінці застосування принщипу безперервності управлінським персоналом підприємства визначено джерело основної проблеми, що перешкоджсє розробленню єдиного методологічного підходу до використання міжнародних стандартів аудиту у вітчизняній практиці, та надано пропозиції щзодо ї̈ вирішення. Окрему увагу приділено методичним рекомендаціям з відображення вимог стандартів у робочих документах аудитора.

Ключові слова: аудит, міжнародні стандарти аудиту, припущення про безперервність, фінансова звітність, робочі документи.

С. В. СЕЛИЩЕВ, кандидат экономических наук, доцент Наџионального центра учета и аудита, Национальная академия статистики, учета и аудита

\section{Отдельные вопросы использования международных стандартов аудита при оценке применения принципа непрерывности управленческим персоналом предприятия}

В рамках исследования отдельных вопросов использования аудита при оценке применения принципа непрерывности управленческим персоналом определен источник основной проблемы, препятствующей разработке единого методологического подхода к использованию стандартов аудита в отечественной практике, и даны предложения по 